\title{
Biogenic Mn oxides for effective adsorption of Cd from aquatic environment
}

\author{
You-Ting Meng ${ }^{\mathrm{a}, \mathrm{b}}$, Yuan-Ming Zheng ${ }^{\mathrm{a}}$, Li-Mei Zhang ${ }^{\mathrm{a}}$, Ji-Zheng He ${ }^{\mathrm{a}, *}$ \\ a State Key Laboratory of Urban and Regional Ecology, Research Center for Eco-environmental Sciences, Chinese Academy of Sciences, Beijing 100085, China \\ ${ }^{\mathrm{b}}$ Graduate School, Chinese Academy of Sciences, Beijing 100039, China \\ Biogenic Mn oxides effectively adsorb Cd from aquatic environments.
}

\section{A R T I C L E I N F O}

\section{Article history:}

Received 19 November 2008

Received in revised form

22 February 2009

Accepted 25 February 2009

\section{Keywords:}

Biogenic Mn oxides

Adsorption

Heavy metal

Cd

Aquatic environment

\begin{abstract}
A B S T R A C T
Biogenic Mn oxides exert important controls on trace metal cycling in aquatic and soil environments. A Mn-oxidizing bacterium Bacillus sp. WH4 was isolated from Fe-Mn nodules of an agrudalf in central China. The biogenic Mn oxides formed by mediation of this Mn oxidizing microorganism were identified as short-ranged and nano-sized $\mathrm{Mn}$ oxides. Cd adsorption isotherms, pH effect on adsorption and kinetics were investigated in comparison with an abiotic Mn oxide todorokite. Maximum adsorption of $\mathrm{Cd}$ to the biogenic Mn oxides and todorokite was 2.04 and $0.69 \mathrm{mmol} \mathrm{g}^{-1}$ sorbent, respectively. Thus, the biogenic Mn oxides were more effective Cd adsorbents than the abiotic Mn oxide in the aquatic environment. The findings could improve our knowledge of biogenic Mn oxides formation in the environment and their important roles in the biogeochemical cycles of heavy metals.
\end{abstract}

(c) 2009 Elsevier Ltd. All rights reserved.

\section{Introduction}

Manganese oxides (Mn oxides) are highly reactive mineral phases that play important roles in elemental biogeochemical cycles. They participate intensely in a wide variety of redox and adsorption reactions with heavy metals. Microorganisms can accelerate the rate of $\mathrm{Mn}$ oxidization processes by up to $10^{5}$ times compared to abiotic Mn oxidation (Hastings and Emerson, 1986). In the absence of microorganisms Mn oxidation in natural aquatic system often proceeds at very slow rates although it is thermodynamically favorable (Nealson et al., 1988). Therefore, the majority of naturally environmental $\mathrm{Mn}$ oxides are believed to be derived either directly from biogenic Mn oxidation processes or from the subsequent alteration of biogenic Mn oxides (Kim et al., 2003; Tebo et al., 2004).

Laboratory research directed toward the bacterial Mn oxidation has focused on three model microorganisms: Leptothrix discophora SS-1 (Corstjens et al., 1997) and SP-6 (Saratovsky et al., 2006), a freshwater bacterial species that deposits Mn oxides on its extracellular sheath; Pseudomonas putida MnB1 and GB-1 (Caspi et al., 1996; Caspi et al., 1998), common freshwater and soil bacteria that precipitate Mn oxides on the cell surface (Villalobos et al., 2003); and Bacillus sp. SG-1 (Van Waasbergen et al., 1996), a marine bacterium that produces Mn oxidizing spores. Biogenic Mn oxides

\footnotetext{
* Corresponding author. Tel./fax: +8610 62849788.

E-mail address: jzhe@rcees.ac.cn (J.-Z. He).
}

are often speculated to be poorly crystalline, short-ranged or amorphous nano-particulates. Kim et al. (2003) demonstrated that biogenic Mn oxides formed by $L$. discophora SP-6 are nano-sized, todorokite-like porous $\mathrm{MnO}_{2}$. The $\mathrm{Mn}$ oxides produced by $P$. putida MnB1 are a poorly crystalline birnessite with hexagonal symmetry and each of the biogenic Mn oxides contains an average of only three stacked sheets and extends for roughly 8-9 $\mathrm{nm}$ in the horizontal plane, making them truly nano-particles (Villalobos et al., 2003). Such nano-sized biogenic Mn oxides are expected to be highly reactive with heavy metal ions (Villalobos et al., 2006).

Thus, the interactions between biogenic Mn oxides and heavy metals have been of great interest for their important roles in the biogeochemical cycles of heavy metals and their potential use in bioremediation of aquatic environments contaminated with toxic metals (Tournassat et al., 2002; Tani et al., 2004; Villalobos et al., 2005a; Wu et al., 2005; Webb et al., 2006). Techniques based on synchrotron radiation such as X-ray absorption near edge structure (XANES) spectroscopy and extended X-ray absorption fine structure (EXAFS) spectroscopy have contributed to the better understanding of heavy metal ions associated with biogenic Mn oxides. Biogenic Mn oxides formed by $L$. discophora SS-1 show higher capacity to adsorb $\mathrm{Pb}$ ions than abiotic Mn oxides because of both higher surface areas and higher binding energy per unit area of the biogenic Mn oxides (Nelson et al., 1999, 2002). XANES and EXAFS results from Villalobos et al., (2005a,b) suggested that the large variation in $\mathrm{Pb}$ retention capacity can be divided into two types of $\mathrm{Pb}$, one residing in the interlayer region of a crystallite and another residing on its external surfaces. $\mathrm{Zn}$ was adsorbed to biogenic $\mathrm{Mn}$ 
oxides in tetrahedral coordination to structural $\mathrm{O}$ atoms at low $\mathrm{Zn}$ loading, but in octahedral coordination at higher $\mathrm{Zn}$ loading (Toner et al., 2006). All these results suggest that the adsorption characteristics of biogenic Mn oxides appear to be different from the abiotic Mn oxides.

$\mathrm{Cd}$ is a hazardous heavy metal, but no studies are yet available on its adsorption to biogenic Mn oxides. The purpose of this study was to characterize Cd adsorption to biogenic Mn oxides, and to infer on possible adsorption mechanisms. The biogenic Mn oxides were formed by Bacillus sp. WH4, a Mn oxidizing bacterium isolated from $\mathrm{Fe}-\mathrm{Mn}$ nodules collected from the soil in central China (Zhang et al., 2008). Cd adsorption isotherms, pH effect and kinetics were conducted to characterize Cd adsorption to the biogenic Mn oxides in comparison with an abiotic Mn oxide todorokite.

\section{Materials and methods}

\subsection{Preparation and characterization of Mn oxides}

Bacillus sp. WH4 was isolated from Fe-Mn nodules which were collected at $40 \mathrm{~cm}$ depth from the subsoil horizon of a subacid orthic agrudalf developed from Quaternary siliceous and alluvial sediments of the Hubei Province, Central China (He et al., 2008; Zhang et al., 2008). This bacterium was grown in modified $\mathrm{K}$ medium (Rosson and Nealson, 1982; Boogerd and de Vrind, 1987; Jin et al., 2009) at $27^{\circ} \mathrm{C}$ for 14 days. The medium contained $\left(\mathrm{l}^{-1}\right): 2 \mathrm{~g}$ of tryptone (Oxoid Ltd, UK), $0.5 \mathrm{~g}$ of yeast extract (Oxoid Ltd, UK), $10 \mathrm{mM}$ HEPES ( $N$-2-hydroxyethylpiperazine- $N^{\prime}$-2-ethanesulfonic acid, Amresco Inc, USA), pH 7.5, $10 \mathrm{mM} \mathrm{MnCl}_{2}, 50 \%$ of artificial seawater (ASW: $0.3 \mathrm{M} \mathrm{NaCl}, 0.01 \mathrm{M} \mathrm{KCl}, 0.05 \mathrm{M} \mathrm{MgSO}_{4}$ and $0.01 \mathrm{M} \mathrm{CaCl}_{2}$ ) and $1 \mathrm{ml}$ trace element solution. The trace element solution contained $\left(\mathrm{l}^{-1}\right): 10 \mathrm{mg}$ of $\mathrm{CuSO}_{4} \cdot 5 \mathrm{H}_{2} \mathrm{O}$, $44 \mathrm{mg}$ of $\mathrm{ZnSO}_{4} \cdot 7 \mathrm{H}_{2} \mathrm{O}, 20 \mathrm{mg}$ of $\mathrm{CoCl}_{2} \cdot 6 \mathrm{H}_{2} \mathrm{O}$ and $13 \mathrm{mg}$ of $\mathrm{Na}_{2} \mathrm{MoO}_{4} \cdot 2 \mathrm{H}_{2} \mathrm{O}$. Prior to the addition of HEPES and $\mathrm{MnCl}_{2}$, the medium was autoclaved for $30 \mathrm{~min}$ at $115^{\circ} \mathrm{C}$. Then sterilized HEPES $(0.22 \mu \mathrm{m}$ filters, $\mathrm{pH} 7.5)$ and $\mathrm{MnCl}_{2}$ were added before inoculation. After 14 days, the fresh biogenic Mn oxides suspension was harvested and stored at $4{ }^{\circ} \mathrm{C}$ before use. The kinetics of biogenic Mn oxides formation was determined at the same time. Biogenic Mn oxides concentration was detected by LBB assay (Krumbein and Altmann, 1973). Todorokite (Feng et al., 2004) was mixed with deionized water to make a stock suspension and kept at $4{ }^{\circ} \mathrm{C}$ prior to use. The formed biogenic Mn oxides were characterized by BET specific surface area, XRD, SEM-EDS and TEM.

\subsection{Batch adsorption tests}

A Cd stock solution was prepared with $\mathrm{Cd}\left(\mathrm{NO}_{3}\right)_{2}$ (Beijing Chemical $\mathrm{Co}$, China) and kept acidic in $1 \% \mathrm{HNO}_{3}$ at $4{ }^{\circ} \mathrm{C}$ to be further diluted before use. Each test solution contained a certain amount of $\mathrm{Cd}$ stock solution, $0.1 \mathrm{~g} \mathrm{l}^{-1} \mathrm{Mn}$ oxide sorbent and $0.01 \mathrm{M} \mathrm{NaNO}_{3}$ to make up $20 \mathrm{ml}$ mixtures in $100 \mathrm{ml}$ centrifugal tubes. The initial $\mathrm{pH}$ of the mixtures was selected carefully to ensure that no precipitation occurred in the solutions according to the $K_{\mathrm{sp}}$ of $\mathrm{Cd}(\mathrm{OH})_{2}\left(K_{\mathrm{sp}}\left(\mathrm{Cd}(\mathrm{OH})_{2}\right)=5.27 \times 10^{-15}\right)$. The initial solution $\mathrm{pH}$ values were adjusted with $0.1 \mathrm{M} \mathrm{NaOH}$ and $0.1 \mathrm{M} \mathrm{HNO}_{3}$. All batch experiments were carried out on a reciprocating shaker at $150 \mathrm{rpm}$ and $25 \pm 1{ }^{\circ} \mathrm{C}$ with three replicates. The $\mathrm{Cd}$ adsorption isotherms and $\mathrm{pH}$ effect experiments were conducted for $4 \mathrm{~h}$ while the kinetic experiments lasted for $24 \mathrm{~h}$.

For $\mathrm{Cd}$ adsorption isotherms, each tube contained various $\mathrm{Cd}$ concentrations ( 0.01 to $0.80 \mathrm{mM}$ ) and initial solution $\mathrm{pH}$ was adjusted to 7.5 . To determine the effect of solution $\mathrm{pH}$ on $\mathrm{Cd}$ adsorption ( $\mathrm{pH}$ effect experiment), initial Cd concentration was $0.1 \mathrm{mM}$ and initial $\mathrm{pH}$ values were between 2.7 and 8.3. To determine the rate of $\mathrm{Cd}$ adsorption by the Mn oxides (kinetics experiment), Cd adsorbed was determined after $0,0.5,1,2,4,6,8,10$, and $24 \mathrm{~h}$.

All the reaction products were centrifuged $(11000 \mathrm{rpm}, 5 \mathrm{~min})$ and filtered through a $0.22 \mu \mathrm{m}$ filter. The obtained supernatants were acidified in $1 \% \mathrm{HNO}_{3}$ and stored at $4{ }^{\circ} \mathrm{C}$ for $\mathrm{Cd}$ and $\mathrm{Mn}$ determination by ICP-AES.

\subsection{Measurements}

The reductive dye Leucoberbelin blue I (LBB) (Sigma, USA) was used to estimate the Mn oxides concentration on a Spectra max190 reader (MD Co. Ltd.) Oxidized LBB is blue in color and the degree of coloration is a function to quantify the amount of $\mathrm{Mn}$ oxides (assuming all oxidized $\mathrm{Mn}$ exist as $\mathrm{MnO}_{2}$ ) being reduced. Suspension of the Mn oxides were added to $0.2 \mathrm{ml}$ of $0.04 \%$ LBB in $45 \mathrm{mM}$ acetic acid, incubated in the dark for $15 \mathrm{~min}$, and then centrifuged for $10 \mathrm{~min}$ at $11000 \mathrm{rpm}$. The supernatant was aliquoted into 96 well plates for $\mathrm{OD}_{620}$ measurement. The LBB assay was also utilized to indicate the kinetics of biogenic Mn oxides formation by Bacillus sp. WH4. The cell optical density (OD600) was measured with a spectrophotometric method at $600 \mathrm{~nm}$.

The specific surface area of the biogenic Mn oxides was measured by BET- $\mathrm{N}_{2}$ method with a Micromeritics ASAP 2000 analyzer. For the BET surface area analysis,

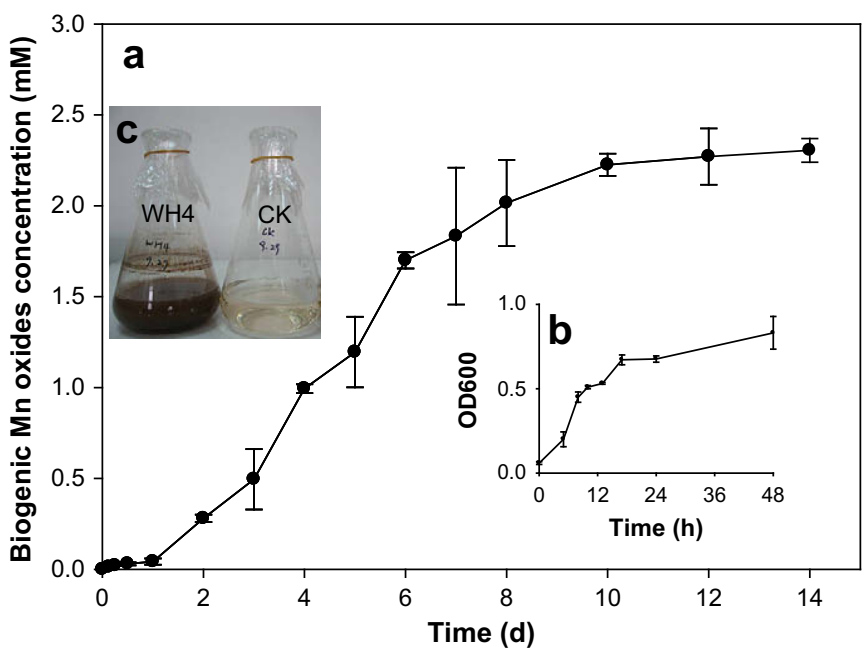

Fig. 1. Kinetics of biogenic Mn oxides formation by Bacillus sp. WH4 (a), growth curve (OD600) of Bacillus sp. WH4 (b) and the photo of brown-black biogenic precipitates (c). The error bars are the standard deviation of three replicates.

the samples were centrifuged, followed by freeze-drying at $-40{ }^{\circ} \mathrm{C}$ for 1 week. They were stored in a desiccator before measurement. XRD analysis was carried out on a revised D/max-rA $12 \mathrm{KW}$ X-ray diffraction instrument. The samples were placed on low-background quartz plates and scanned over the range $2 \theta=2.6-70^{\circ}$. The $\mathrm{Mn}$ oxides morphology and chemical contents were determined by SEM with an EDAX KEVEX level 4 (Hitachi S-3500N), and TEM (Hitachi H-7500, Japan). For SEM and TEM, the samples were prepared as biological samples. SEM biological samples were fixed with $2.5 \%$ (volume ratio) glutaraldehyde for $4.5 \mathrm{~h}$ at $4{ }^{\circ} \mathrm{C}$, followed by dehydration with an ethanol series (30\% (volume ratio), 50\%, 70\%, $80 \%, 90 \%, 95 \%$, and $100 \% ; 5$ min for each). TEM biological samples were prepared by fixation with $2.5 \%$ (volume ratio) glutaraldehyde overnight at $4{ }^{\circ} \mathrm{C}$, and then ultrasonic dispersion for $30 \mathrm{~min}$. At last $10 \mu \mathrm{l}$ suspension was dropped to copper grids, and the excessive solvent immediately evaporated. Total $\mathrm{Cd}$ and $\mathrm{Mn}$ concentrations in the final supernatants were determined by inductively coupled plasma spectroscopy (ICPAES, Prodigy, Leeman Labs).

\subsection{Data analysis}

The Cd adsorption from solution by $\mathrm{Mn}$ oxides ( $q, \mathrm{mmol} \mathrm{Cd} \mathrm{g}^{-1}$ sorbent) was quantified as:

$q=\left([C d]_{t}-[C d]_{0}\right) /[$ sorbent $]$

where $[\mathrm{Cd}]_{0}$ and $[\mathrm{Cd}]_{\mathrm{t}}$ are the $\mathrm{Cd}$ concentrations at time 0 and time $t$ in solution $(\mathrm{mM})$, [sorbent] is the dry sorbent in mixture $\left(\mathrm{g} \mathrm{l}^{-1}\right)$.

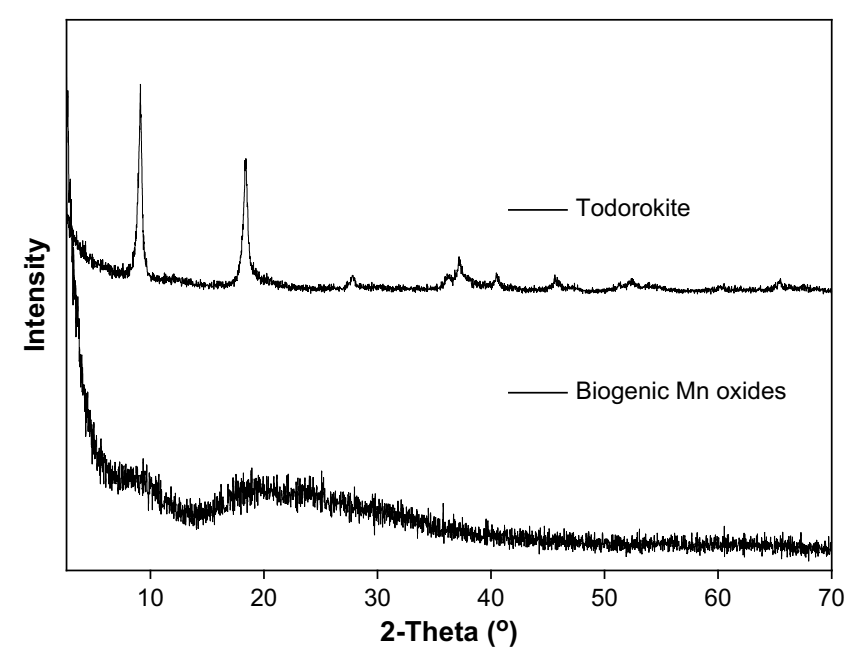

Fig. 2. XRD patterns of todorokite and biogenic Mn oxides. 

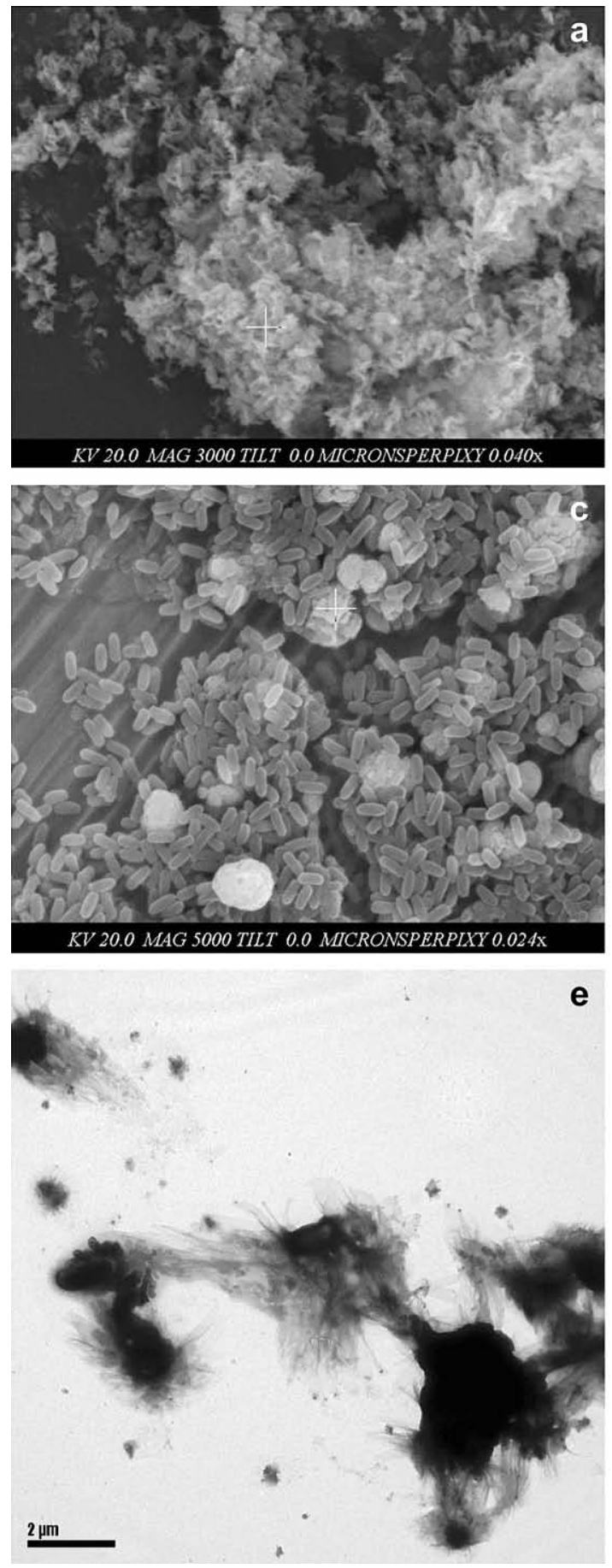

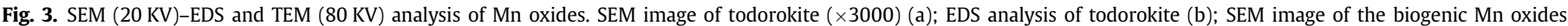
$(\times 5000)(\mathrm{c})$; EDS analysis of the biogenic Mn oxides (d); TEM image of the fresh biogenic Mn oxides formed by Bacillus sp. WH4 ((e), $\times 10000$; $\mathrm{f}, \times 500000)$.

The adsorption capacity of Mn oxides was described using the Freundlich model (Sposito, 2004):

$q=A C^{1 / n}$

where $q$ is the amount of $C d$ adsorbed ( $m o l ~ C d ~ g^{-1}$ ) sorbent; $C$ is the equilibrium $\mathrm{Cd}$ concentration in the mixture $(\mathrm{mM})$; and $A$ and $1 / n$ are empirical constants.

To understand the kinetics of Cd adsorption, the kinetic adsorption data were modeled empirically with the pseudo-first order Lagergren model (Lagergren, 1898). The Lagergren model is a widely used sorption rate model for the sorption of a solute from a liquid solution. It may be represented as:

$\log \left(q_{e}-q_{t}\right)=\log q_{e}-\left(K_{a d} / 2.303\right) t$
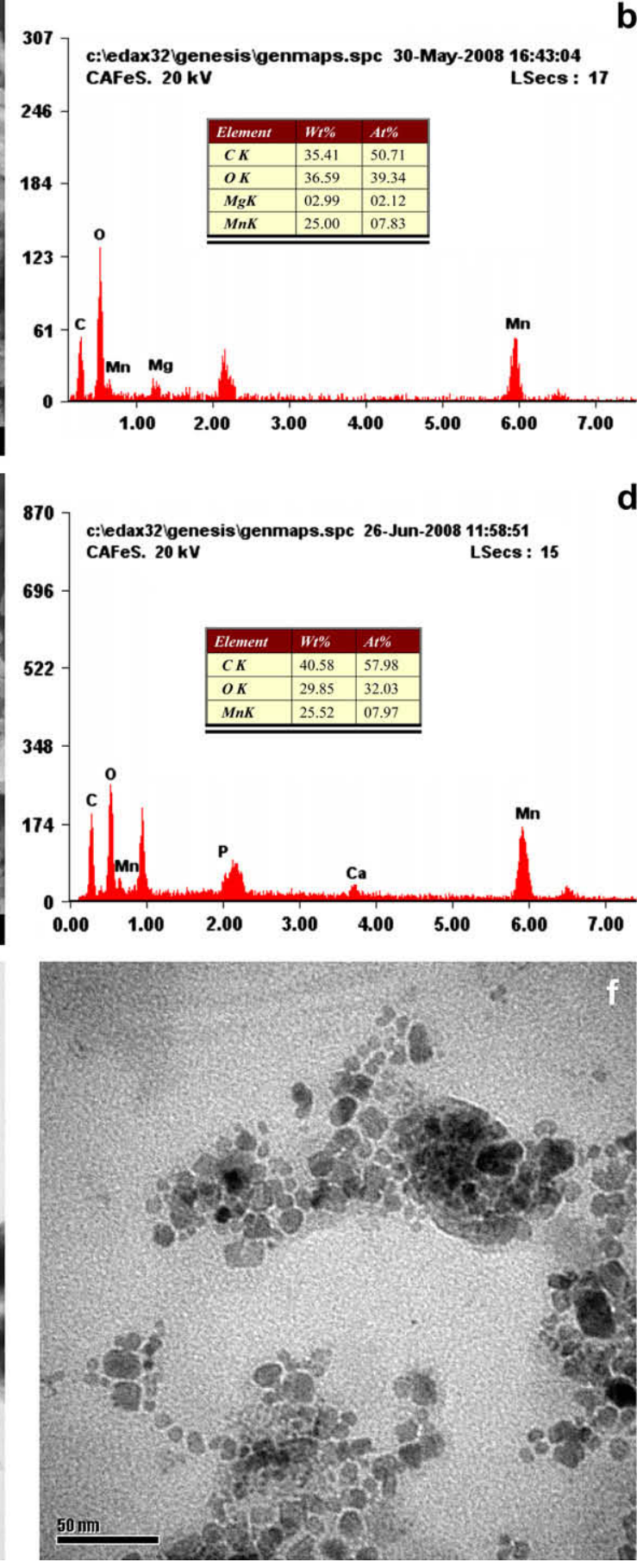

b

d 


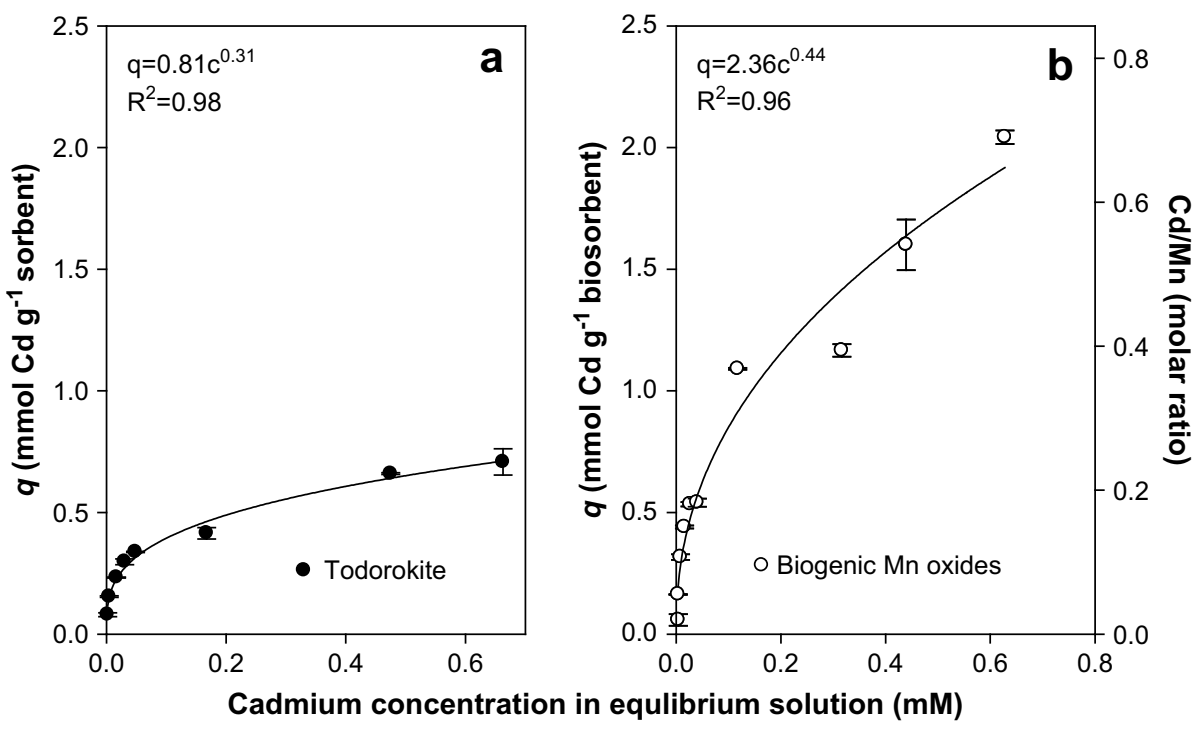

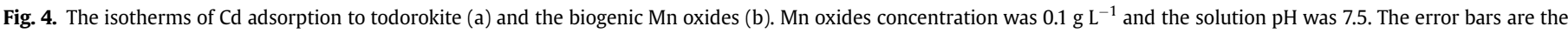
standard deviation of three replicates.

microscope. As shown in Fig. 1, the Mn oxidation rate began to increase quickly within the first 7 days, and brown-black precipitates were formed. By contrast, there was no change in the control medium (CK), which containing only $10 \mathrm{mM} \mathrm{MnCl}_{2}$ (no Bacillus sp. WH4) (Fig.1c). The biogenic Mn oxides formation reached a plateau at day 10 and the fresh biogenic Mn oxides were harvested at day 14 with $2.3 \mathrm{mM} \mathrm{MnO}_{2}$.

\subsection{Characterization of biogenic Mn oxides}

\subsubsection{XRD patterns}

There were no obvious crystalline peaks on the XRD patterns of the biogenic Mn oxides (Fig. 2), which indicated that they were poorly crystallized. No detectable changes were found in the XRD patterns for our samples with preservation as suspension for several months. The XRD pattern of todorokite was consistent with todorokite standards from mineral index files provided by the Joint Committee for Powder Diffraction Studies (JCPDS-ICDD).

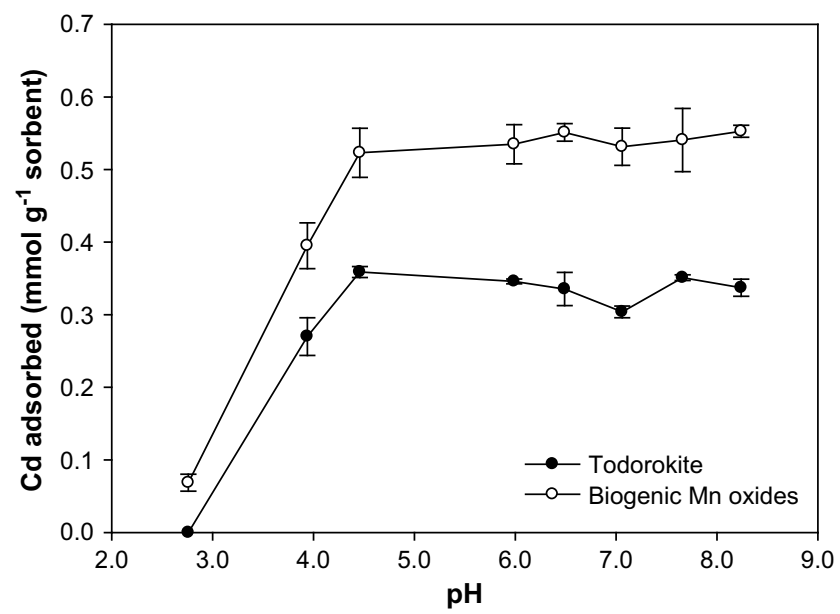

Fig. 5. Effects of $\mathrm{pH}$ on $\mathrm{Cd}$ adsorption by $\mathrm{Mn}$ oxides in the $\mathrm{pH}$ range of 2.7-8.2. Initial $\mathrm{Cd}$ concentration was $0.1 \mathrm{mM}$ and $\mathrm{Mn}$ oxides concentration was $0.1 \mathrm{~g} \mathrm{~L}^{-1}$. The error bars are the standard deviation of three replicates.

\subsubsection{Physicochemical characteristics}

The morphology and surface elements distribution of the Mn oxides were studied by SEM-EDS and TEM (Fig. 3). The SEM image of the todorokite showed that it was well crystallized (Fig. 3a). By contrast, the images of the biogenic Mn oxides were aggregated particles with irregular geometric shape, indicating their poor crystallinity and very small particle size. These fine particles had densely aggregated filamentous structures. Some deposits directly adhered to the surface of the spores, while others distributed around the spores (Fig. 3e). The EDS analysis indicated that the Mn oxidation activity was not only located on the spore surface, but also excreted into the surrounding culture medium (Fig. 3d). The TEM image of biogenic Mn oxides (Fig. 3f) shows clearly that the biogenic Mn oxides were nano-sized. The BET specific surface area of freeze-dried biosorbent and pure spores were $30.6 \mathrm{~m}^{2} \mathrm{~g}^{-1}$ and $2.4 \mathrm{~m}^{2} \mathrm{~g}^{-1}$, respectively.

\subsection{Adsorption isotherm}

The biogenic Mn oxides adsorbed $2.04 \mathrm{mmol} \mathrm{Cd} \mathrm{g} \mathrm{g}^{-1}$ biosorbent at the highest initial $\mathrm{Cd}$ concentration, which corresponds to a $\mathrm{Cd}$ $\mathrm{Mn}$ molar ratio of 0.69 . The todorokite adsorbed $0.71 \mathrm{mmol} \mathrm{Cd} \mathrm{g}^{-1}$ sorbent, which was less than the biogenic Mn oxides (Fig. 4). The Freundlich model was suitable for the present systems. The Langmuir model, in contrast, was not suitable to describe the adsorption isotherms (data not shown).

\section{4. $\mathrm{pH}$ effect on Cd adsorption}

The results in Fig. 5 illustrate the effects of $\mathrm{pH}$ on $\mathrm{Cd}$ adsorption to $\mathrm{Mn}$ oxides. The $\mathrm{Cd}$ adsorption was evidently dependent on $\mathrm{pH}$ for both of the Mn oxides. The adsorption capacity increased steadily with increasing $\mathrm{pH}$ up to $\mathrm{pH} 4.5$ and then slowed down with a plateau at $\mathrm{pH}$ 4.5-8.3. The maximum adsorption capacity approached 0.36 and $0.54 \mathrm{mmol} \mathrm{g}^{-1}$ sorbent for todorokite and biogenic Mn oxides, respectively.

\subsection{Kinetics adsorption}

Kinetic experiments were performed to determine Cd adsorption rates by the two Mn oxides. As shown in Fig. 6, the rates of 

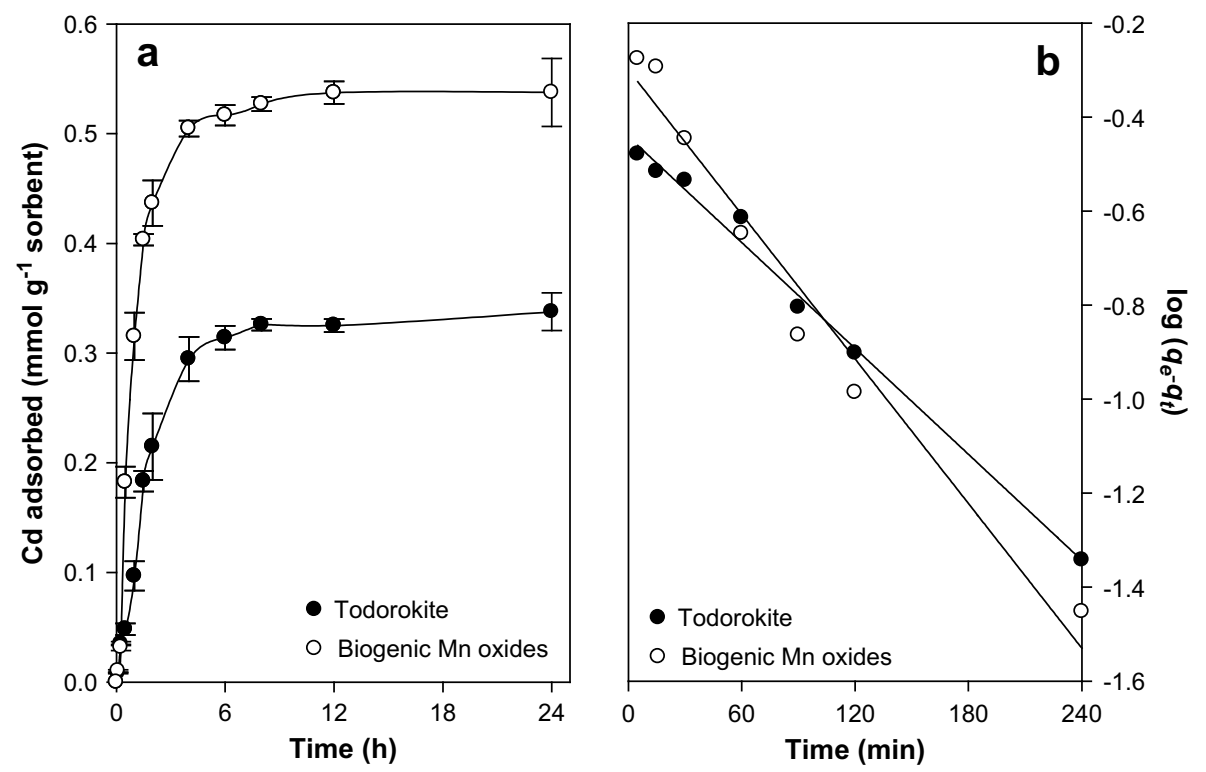

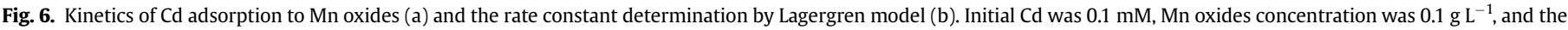
solution $\mathrm{pH}$ was 7.5. The error bars are the standard deviation of three replicates.

adsorption were very fast initially and then reached a plateau at equilibrium. For both Mn oxides, maxima were obtained within $12 \mathrm{~h}$. The changes in the adsorption capacity with time was found to fit Lagergren model with the straight-line plots of $\log \left(q_{e}-q_{t}\right)$ versus $t$ (Fig. 6b). The values of $K_{\mathrm{ad}}$, the rate constants, were calculated to be $1.17 \times 10^{-2} \mathrm{~min}^{-1}$ for the biogenic Mn oxides and $0.76 \times 10^{-2} \mathrm{~min}^{-1}$ for the todorokite. The $K_{\mathrm{ad}}$ values indicated that the adsorption rate of $\mathrm{Cd}$ adsorbed to the biogenic Mn oxides was faster than to the todorokite.

To understand the possible mechanism of $\mathrm{Cd}$ adsorption to the biogenic Mn oxides, the changes of Mn concentration in solution and $\mathrm{pH}$ values in the kinetics experiment were determined. Mn concentration and $\mathrm{pH}$ value of control, in which no $\mathrm{Cd}$ was added (only $\mathrm{Mn}$ oxides and $\mathrm{NaNO}_{3}$ solution), were also assessed. During $\mathrm{Cd}$ adsorption to the biogenic Mn oxides, more $\mathrm{Mn}$ in solution was detected than CK (Fig. 7a). However, this phenomenon was not observed when $\mathrm{Cd}$ adsorbed to the todorokite. For $\mathrm{pH}$ value, the trends of biogenic Mn oxides and todorokite were similar, i.e., quick decreasing and then keeping smooth (Fig. 7b).

\section{Discussion}

In this study, the biosorbent was actually a mixture of biogenic Mn oxide particulates and spores, and the BET specific surface area was the value of this mixture. Therefore, it is not surprised that the BET specific surface area of the biosorbent was lower than that of the todorokite $\left(77 \mathrm{~m}^{2} \mathrm{~g}^{-1}\right.$ ) (Feng et al., 2004) and values reported in other studies (Nelson et al., 1999; Villalobos et al., 2006). The spores, wrapped by the fine biogenic Mn oxides particulate (Fig. 3e), may be considered to have little effect on the adsorption

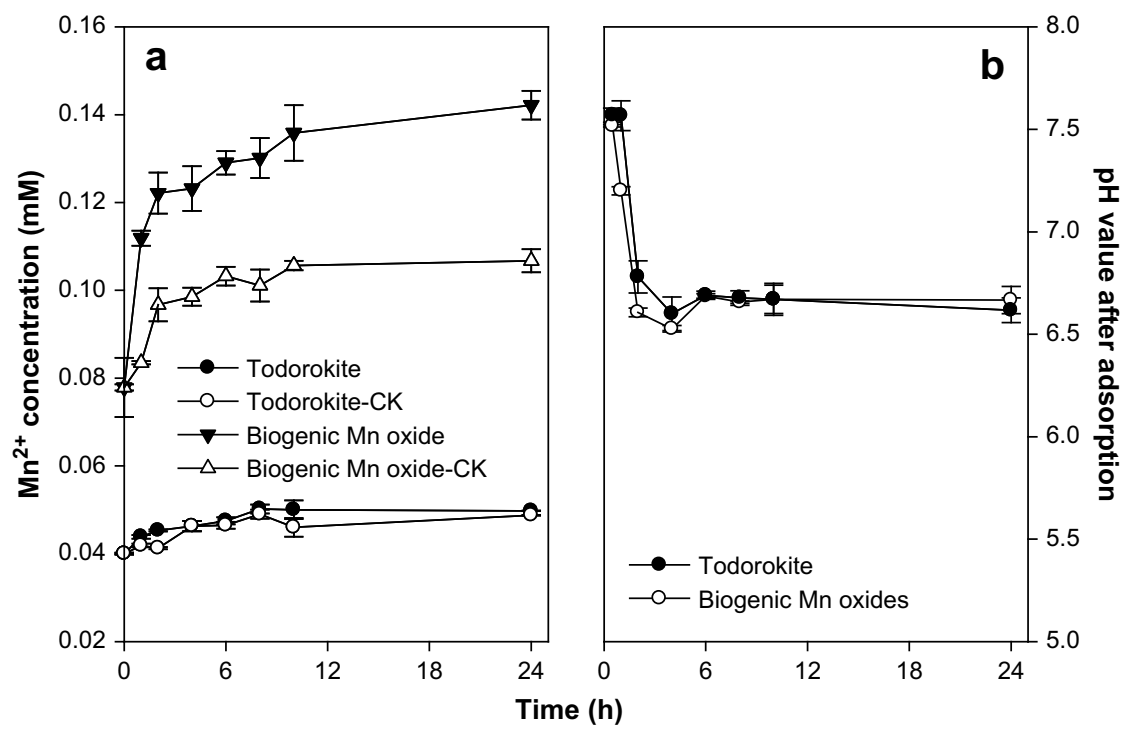

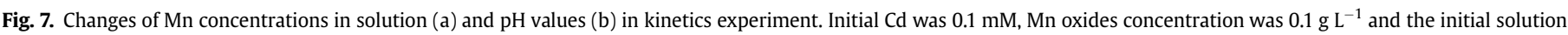
$\mathrm{pH}$ was 7.5. The error bars are the standard deviation of three replicates. 
process. Toner et al., (2006) and Sasaki et al., (2008) also reported that the biogenic functional groups present in the biofilm do not intervene in metal adsorption to the biogenic Mn oxides.

It is not surprising that the Langmuir equation failed in describing the adsorption behavior, and this result is consistent with the result of $\mathrm{Zn}$ adsorbed to biogenic Mn oxides produced by $P$. putida strain MnB1 (Toner et al., 2006). Langmuir model assumes that the adsorption is the coverage of the surface by a monomolecular layer. This assumption may be not suitable for the adsorption to the Mn oxides, especially to the biogenic Mn oxides. $\mathrm{Cd}$ adsorption capacity to the biogenic Mn oxides was about three times greater than to the todorokite. This result was similar with $\mathrm{Pb}$ adsorption to biogenic Mn oxides formed by L. discophora (2-5 times greater than adsorption to fresh $\delta-\mathrm{MnO}_{2}$ ) (Nelson et al., 1999). Table 1 shows maximum adsorption of metals on several biogenic Mn oxides as reported in literature. The data show that the maximum adsorption of diverse biogenic Mn oxides, expressed as metal/Mn molar ratio, varies from 0.12 to 0.76 between metals.

Although the biogenic $\mathrm{Mn}$ oxides have shown a higher adsorption capacity and a higher adsorption rate for heavy metals, the characteristics and mechanisms of metal adsorption to biogenic Mn oxides are still unclear because the biogenic Mn oxides are amorphous, nano-sized and often mixed with organisms. Metal adsorption to Mn oxides could occur through three pathways (Tebo et al., 2004; Miyata et al., 2007): (a) surface adsorption on layers or edges of Mn oxides involving the formation of either inner sphere or outer sphere complexes; (b) sorption into the interlayer regions or tunnels; and (c) incorporation into vacancies or substitution for Mn within the mineral lattice structure. In our kinetic experiment, changes in pH were observed when Cd adsorbed to both Mn oxides, while a significant Mn concentration change was only detected in the case of biogenic Mn oxides. Since the biogenic Mn oxides were poorly crystalline and rich in nano-sized fine pores, a part of exchangeable charge-balancing cations, such as $\mathrm{Mn}^{2+}$ and $\mathrm{H}^{+}$are loosely involved in the structure to compensate the charge balance. These structural $\mathrm{Mn}^{2+}$ and $\mathrm{H}^{+}$could be easily exchanged by $\mathrm{Cd}$ ions during the adsorption process. By contrast, the todorokite is a well crystallized Mn oxide with average Mn oxidation state 3.82 (Feng et al., 2004). Less $\mathrm{Mn}(\mathrm{II})$ or $\mathrm{Mn}(\mathrm{III})$ could exist in the lattice structure of the todorokite and be exchanged during $\mathrm{Cd}$ adsorption to the todorokite. Therefore, the greater adsorption to nano-sized biogenic Mn oxides is likely due to the amorphous or short-ranged nature and more reactive cation exchange sites of the biogenic Mn oxides compared to those of the more crystalline abiotic Mn oxide. The biogenic Mn oxides may also have greater binding energy per unit surface area than the chemical Mn oxides (Nelson et al., 1999).

The Mn oxides, biogenic or abiotic, were affected by the solution $\mathrm{pH}$. Lower $\mathrm{pH}$ is favorable for the protonation of the sorbent surface. Increased protonation is thought to increase the positively charged sites, reduce the attraction force between the Mn oxides surface and Cd ions, and decrease the amount of adsorption in the

\section{Table 1}

Maximum adsorption of metals on biogenic Mn oxides expressed as a molar ratio of metal to $\mathrm{Mn}$.

\begin{tabular}{|c|c|c|c|}
\hline Metals & $\begin{array}{l}\text { Maximum adsorption } \\
\text { (metal/Mn, molar ratio) }\end{array}$ & $\begin{array}{l}\text { Biogenic Mn } \\
\text { oxides sources }\end{array}$ & References \\
\hline$\overline{\mathrm{Pb}}$ & $0.55, \mathrm{pH} 6.0$ at $25^{\circ} \mathrm{C}$ & L. discophora & (Nelson et al., 1999) \\
\hline $\mathrm{Pb}$ & 0.27 , pH 5.8 at $23^{\circ} \mathrm{C}$ & P. putida strain MnB1 & (Villalobos et al., 2005a) \\
\hline Zn & $0.76, \mathrm{pH} 6.9$ at $20^{\circ} \mathrm{C}$ & P. putida strain MnB1 & (Toner et al., 2006) \\
\hline $\mathrm{Zn}$ & $0.23, \mathrm{pH} 7.0$ at $25^{\circ} \mathrm{C}$ & Acremonium sp. KR21-2 & (Tani et al., 2004) \\
\hline $\mathrm{Ni}$ & $0.12, \mathrm{pH} 7.0$ at $25^{\circ} \mathrm{C}$ & Acremonium sp. KR21-2 & (Tani et al., 2004) \\
\hline Co & $0.30, \mathrm{pH} 7.0$ at $25^{\circ} \mathrm{C}$ & Acremonium sp. KR21-2 & (Tani et al., 2004) \\
\hline Co & $0.16, \mathrm{pH} 6.5$ at $25^{\circ} \mathrm{C}$ & $\begin{array}{l}\text { Paraconiothyrium sp. } \\
\text { WL-2 }\end{array}$ & (Sasaki et al., 2008) \\
\hline $\mathrm{Cd}$ & $0.69, \mathrm{pH} 7.5$ at $25^{\circ} \mathrm{C}$ & Bacillus sp. WH4 & Present study \\
\hline
\end{tabular}

lower $\mathrm{pH}$ region. With increasing $\mathrm{pH}$, the negatively charged sites dominate and adsorption increases. The high adsorption capability of the biogenic Mn oxides within wide $\mathrm{pH}$ ranges (4.5-8.3) indicates its potential to control the fate of heavy metals in the natural environment.

In this study, the fresh biogenic Mn oxides were formed by Bacillus sp. WH4, a Mn oxidizing bacterium which was isolated from the subsoil. The results provide evidence that the $\mathrm{Mn}$ oxidizing bacteria and biogenic Mn oxides may play important roles in various environments, more than previously acknowledged. The biogenic Mn oxides could be formed quickly by $\mathrm{Mn}$ oxidizing bacteria and have a large adsorption capacity of heavy metals in a short time. This could be useful for application in environmental engineering. Further research is needed to characterize the heavy metal adsorption and other properties of the biogenic Mn oxides.

\section{Acknowledgements}

This work was supported by the Ministry of Science and Technology of China (2005CB121104), the Chinese Academy of Sciences (KZCX1-YW-06-03), and the Natural Science Foundation of China (50621804, 40671172).

\section{References}

Boogerd, F.C., de Vrind, J.P., 1987. Manganese oxidation by Leptothrix discophora Journal of Bacteriology 169, 489-494.

Caspi, R., Haygood, M.G., Tebo, B.M., 1996. Unusual ribulose-1,5-bisphosphate carboxylase/oxygenase genes from a marine manganese-oxidizing bacterium. Microbiology 142, 2549-2559.

Caspi, R., Tebo, B.M., Haygood, M.G., 1998. c-Type cytochromes and manganese oxidation in Pseudomonas putida MnB1. Applied and Environmental Microbiology 64, 3549-3555.

Corstjens, P.L.A.M., deVrind, J.P.M., Goosen, T., deVrinddeJong, E.W., 1997. Identification and molecular analysis of the Leptothrix discophora SS-1 mofA gene, a gene putatively encoding a manganese-oxidizing protein with copper domains. Geomicrobiology Journal 14 249-249.

Feng, X.H., Tan, W.F., Liu, F., Wang, J.B., Ruan, H.D., 2004. Synthesis of todorokite at atmospheric pressure. Chemistry of Materials 16, 4330-4336.

Hastings, D., Emerson, S., 1986. Oxidation of manganese by spores of a marine bacillus: kinetic and thermodynamic considerations. Geochimica et Cosmochimica Acta 50, 1819-1824.

He, J.Z., Zhang, L.M., Jin, S.S., Zhu, Y.G., Liu, F., 2008. Bacterial communities inside and surrounding soil iron-manganese nodules. Geomicrobiology Journal 25, 14-24.

Jin, S.S., He, J.Z., Zheng, Y.M., Meng, Y.T., Zhang, L.M., 2009. Adsorption of heavy metals by biogenic manganese oxides. Acta Scientiae Circumstantiae 29, 132-139.

Kim, H.S., Pasten, P.A., Gaillard, J.F., Stair, P.C., 2003. Nanocrystalline todorokite-like manganese oxide produced by bacterial catalysis. Journal of the American Chemical Society 125, 14284-14285.

Krumbein, W.E., Altmann, H.J., 1973. A new method for the detection and enumeration of manganese oxidizing and reducing microorganisms. Helgoland Marine Research 25, 347-356.

Lagergren, 1898. About the theory of so-called adsorption of soluble substances. Kungliga Svenska Vetenskapsakademiens. Handlingar, Band 24, 1-39.

Miyata, N., Tani, Y., Sakata, M., Iwahori, K., 2007. Microbial manganese oxide formation and interaction with toxic metal ions. Journal of Bioscience and Bioengineering 104, 1-8.

Nealson, K.H., Tebo, B.M., Rosson, R.A., Allen, I.L., 1988. Occurrence and mechanisms of microbial oxidation of manganese. Advances in Applied Microbiology 33, 279-318.

Nelson, Y.M., Lion, L.W., Ghiorse, W.C., Shuler, M.L., 1999. Production of biogenic Mn oxides by Leptothrix discophora SS-1 in a chemically defined growth medium and evaluation of their $\mathrm{Pb}$ adsorption characteristics. Applied and Environmental Microbiology 65, 175-180.

Nelson, Y.M., Lion, L.W., Shuler, M.L., Ghiorse, W.C., 2002. Effect of oxide formation mechanisms on lead adsorption by biogenic manganese (hydr)oxides, iron (hydr)oxides, and their mixtures. Environmental Science \& Technology 36, 421-425.

Rosson, R.A., Nealson, K.H., 1982. Manganese binding and oxidation by spores of a marine bacillus. Journal of Bacteriology 151, 1027-1034.

Saratovsky, I., Wightman, P.G., Pasten, P.A., Gaillard, J.F., Poeppelmeier, K.R., 2006 Manganese oxides: parallels between abiotic and biotic structures. Journal of the American Chemical Society 128, 11188-11198.

Sasaki, K., Matsuda, M., Urata, T., Hirajima, T., Konno, H., 2008. Sorption of $\mathrm{Co}^{2+}$ ions on the biogenic $\mathrm{Mn}$ oxide produced by a Mn-oxidizing fungus, Paraconiothyrium sp. WL-2. Materials Transactions 49, 605-611. 
Sposito, G., 2004. The Surface Chemistry of Natural Particles. Oxford University Press, New York.

Tani, Y., Ohashi, M., Miyata, N., Seyama, H., Iwahori, K., Soma, M., 2004. Sorption of $\mathrm{Co}(\mathrm{II}), \mathrm{Ni}(\mathrm{II})$, and $\mathrm{Zn}(\mathrm{II})$ on biogenic manganese oxides produced by a Mn-oxidizing fungus, strain KR21-2. Journal of Environmental Science and Health Part A-Toxic Hazardous Substances \& Environmental Engineering 39, 2641-2660.

Tebo, B.M., Bargar, J.R., Clement, B.G., Dick, G.J., Murray, K.J., Parker, D., Verity, R. Webb, S.M., 2004. Biogenic manganese oxides: properties and mechanisms of formation. Annual Review of Earth and Planetary Sciences 32, 287-328.

Toner, B., Manceau, A., Webb, S.M., Sposito, G., 2006. Zinc sorption to biogenic hexagonal-birnessite particles within a hydrated bacterial biofilm. Geochimica et Cosmochimica Acta 70, 27-43.

Tournassat, C., Charlet, L., Bosbach, D., Manceau, A., 2002. Arsenic(III) oxidation by birnessite and precipitation of manganese(II) arsenate. Environmental Science \& Technology 36, 493-500.

Van Waasbergen, L.G., Hildebrand, M., Tebo, B.M., 1996. Identification and characterization of a gene cluster involved in manganese oxidation by spores of the marine Bacillus sp. strain SG-1. Journal of Bacteriology 178, 3517-3530.
Villalobos, M., Bargar, J., Sposito, G., 2005a. Mechanisms of $\mathrm{Pb}(\mathrm{II})$ Sorption on a biogenic manganese oxide. Environmental Science \& Technology 39, 569-576.

Villalobos, M., Bargar, J., Sposito, G., 2005b. Trace metal retention on biogenic manganese oxide nanoparticles. Elements 1, 223-226.

Villalobos, M., Lanson, B., Manceau, A., Toner, B., Sposito, G., 2006. Structural model for the biogenic Mn oxide produced by Pseudomonas putida. American Mineralogist 91, 489-502.

Villalobos, M., Toner, B., Bargar, J., Sposito, G., 2003. Characterization of the manganese oxide produced by Pseudomonas putida strain MnB1. Geochimica et Cosmochimica Acta 67, 2649-2662.

Webb, S.M., Fuller, C.C., Tebo, B.M., Bargar, J.R., 2006. Determination of uranyl incorporation into biogenic manganese oxides using X-ray absorption spectroscopy and scattering. Environmental Science \& Technology 40, 771-777.

Wu, Y., Deng, B., Xu, H., Kornishi, H., 2005. Chromium(III) oxidation coupled with microbially mediated Mn(II) oxidation. Geomicrobiology Journal 22, 161-170.

Zhang, L.M., Liu, F., Tan, W.F., Feng, X.H., Zhu, Y.G., He, J.Z., 2008. Microbial DNA extraction and analyses of soil iron-manganese nodules. Soil Biology and Biochemistry 40, 1364-1369. 